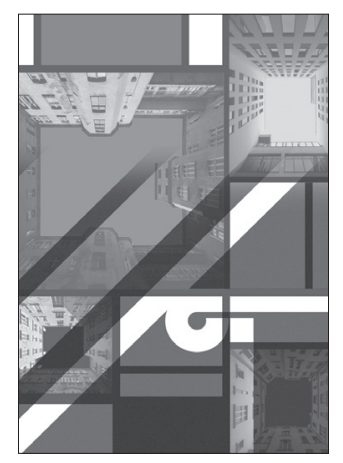

\title{
Michal Suffczyński*
}

\section{Rysunek strukturalny w obrazowaniu przestrzeni i edukacji architektonicznej na Wydziale Architektury Politechniki Warszawskiej wobec tradycji École des Beaux Arts i Bauhausu}

\author{
Structural drawing in the representation of space and architectural \\ education at the Faculty of Architecture of Warsaw University \\ of Technology in relation to the tradition \\ of the École des Beaux Arts and the Bauhaus University
}

\author{
Wprowadzenie. \\ Świat idei i materii \\ w twórczości architektonicznej
}

Przedmiotem artykułu jest funkcja rysunku strukturalnego w twórczości architektonicznej jako metody obrazowania przestrzeni zgodnie z prawami widzenia i perspektywy malarskiej oraz jego rola w kształceniu studentów architektury.

Zasadniczą częścią wykonywania zawodu architekta jest wykorzystanie komunikacji wizualnej umożliwiającej nadanie idei projektowej materialnego zapisu w postaci rysunków, które mogą mieć bardzo różne wyrazy graficzne i stopnie precyzji. Rozwój metod rysunkowego przedstawiania architektury od najdawniejszych przykładów do dzisiejszego zapisu elektronicznego (il. 1) stanowi ciekawą historię relacji idei wobec kształtowania materii. $\mathrm{Na}$ miano sztuki, zgodnie z platońską koncepcją, zasługuje dzieło, które prowadzi nas do prawdy. Świat, który odbieramy za pomocą zmysłów, Platon określa jako odbicie świata idei i prawdy. Potępia on zatem malarstwo naśladowcze, ponieważ nie prowadzi ono do poznania prawdy, a jedynie kopiuje zmysłowe doznania, które już

* ORCID: 0000-0001-7734-1610. Wydział Architektury Politechniki Warszawskiej / Faculty of Architecture, Warsaw University of Technology, e-mail: michalsuffczynski@gmail.com

\author{
Introduction. \\ The ideal and material world \\ in architectural works
}

The article discusses the function of structural drawing in architectural works as a method of picturing space according to the optics and aerial perspective as well as its role in the education of architecture students.

The essential part of the profession of an architect is the use of visual communication that enables a design idea to get a material record in the form of drawings, which can be represented differently and have varying levels of precision. Since the appearance of oldest examples until today's electronic record (Fig. 1), the development of methods of representing architecture by drawings has been an interesting history of the relations of ideas in relation to the formation of matter. According to the Platonic conception, a work of art which leads us to truth deserves to be called art. The world we perceive with our senses is defined by Plato as a reflection of the world of ideas and truth. Therefore, he condemns the imitative painting because it does not lead to the truth but only copies sensory experiences, which are already copies of ideas themselves [1]. Thus, a painter recreates appearances. Art should perform a cognitive function. In this sense, architectural sketches which precede the realization of an actual object, unless they are a copy, deserve 

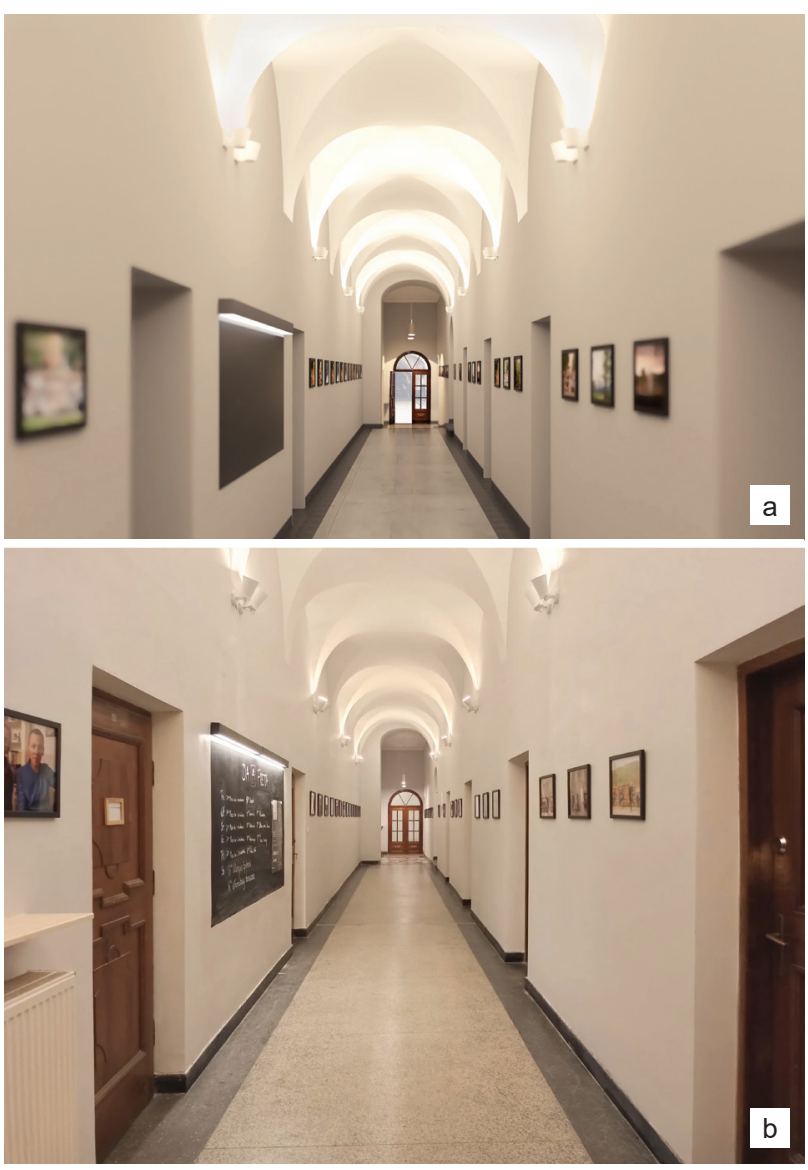

Il. 1. Adaptacja fragmentu krużganka klasztoru dominikanów przy ul. Freta $10 \mathrm{w}$ Warszawie na przestrzeń duszpasterską (proj. T. Szenajch, M. Rygier, A. Chrząstowski-Wachtel):

a) wizualizacja komputerowa (program SketchUp Pro+VRAY, autor: T. Szenajch, 2019),

b) zdjęcie powykonawcze projektu (fot. T. Szenajch, 2020)

Fig. 1. Adaptation of a fragment of the cloister for pastoral space in the Dominican Friars' monastery at Freta Street in Warsaw

(project and realization: T. Szenajch, Eng. M. Rygier, Eng. A. Chrząstowski-Wachtel):

a) Computer visualization (SketchUp Pro+VRAY, author: T. Szenajch, 2019), b) as-built picture (by T. Szenajch, 2020)

same w sobie są kopią idei [1]. Malarz jest więc odtwórcą pozorów. Sztuka zaś powinna pełnić funkcję poznawczą. $\mathrm{W}$ tym rozumieniu szkice architektoniczne poprzedzające rzeczywisty obiekt, o ile nie są kopią, zasługują na miano sztuki. Ciekawym spostrzeżeniem jest to, iż dużo wspólnego $\mathrm{z}$ tą teorią ma abstrakcjonizm oraz podejście do nauczania w szkole Bauhausu, mimo że przedstawiciele tego nurtu nie czerpali bezpośrednio z filozofii Platona. Maria Misiągiewicz przywołuje zdefiniowanie przez Stanleya Allena roli rysunku [...] jako znaku wskazujacego to co nieobecne, [...] ponieważ sam $w$ sobie $w$ petni charakteryzuje budowanie tu i teraz i jako taki jest immanentny dla projektowania [2, s. 14]. Według autorki architekt jest pierwszym obserwatorem własnych rysunków umożliwiających mu ocenę i rozwój idei projektowej ${ }^{1}$. Kendra

1 Konkretyzacja zamysłu projektowego przez rysunek jest według autorki najistotniejszą cechą procesu tworzenia architektury [2, s. 14, $15]$. the name of art. It is worth noticing that abstractionism as well as the approach to teaching represented by the Bauhaus have a lot in common with this theory, even though representatives of this trend did not directly draw from Plato's philosophy. Maria Misiągiewicz refers to Stanley Allen's definition of drawing [...] as a sign which indicates what is absent [...] because it fully characterizes the way of building here and now and as such is immanent for a design process [2, p. 14]. She believes that an architect is the first observer of his own drawings which enable him to evaluate and develop the design idea ${ }^{1}$. Kendra Schank Smith quotes Ernst Gombrich's opinion on the magical function of the first drawings ever made, (e.g., on rocks) and their similarity to building seats protecting people against the power of nature and its spirits ${ }^{2}$. When writing about the specifics of architectural drawing in relation to other types of artistic pictures, Leszek Maluga notices that architectural drawing is assigned to the profession of an architect because it is a material trace of the process of designing space. [...] It means that drawing plays an auxiliary role in this process. However, it is also a base material document at the stage of coming up with an idea and then implementing it in a real space. [...] The cited definition, however, requires elaboration and more detailed discussion due to the variety of creative situations in which graphic records as well as the richness of forms and artistic means used by architects $^{3}$ [4, p. 17]. According to Frank Gehry, an architect is searching for a building by doing his drawings and he compares this effort to the act of carving ${ }^{4}$ (after: [2]). Roman Ingarden believes that an architectural work is created only when a project is materially realized [5, p. 124]. Also from his opinion Misiagiewicz draws a conclusion on [...] the rationale behind a drawing-project as an indispensable element in the process which takes place between coming up with an idea and its implementation. A project is the documentation of an actual work of an architect. Expressing thoughts by a drawing is a creative act. After all, only in this way is it possible to achieve the design goal. This purpose is based on the relationship between thinking and the visual perception, the correlation for which Władystaw Strzemiński argues in his theory of vision ${ }^{5}$ [2, p. 18]. Olgierd Czerner made an important division into two areas of the architectural creation by noticing differences between architectural drawings (those which are expressions of ideas as well as those made for the

1 According to the author, the most essential feature in the process of creating architecture is the representation of a concept by a drawing [2, pp. 14, 15].

2 The art. historian E. H. Gombrich when discussing the origins of art. writes that humans assembled structures to shelter themselves from elements of nature such as rain, as well as from the spirits that controlled the natural environment [3, p. 6].

3 The author believes that architectural drawing is [...] a material trace in the space design process [4, p. 16].

4 The author also says that a drawing is "a stage on the way to construction". Raimund Abraham, on the other hand, expressed a conviction that architectural drawings have an autonomous value even when they do not lead to the construction of a building (after: [2, p. 54]).

5 Cf. [6]. 
Schank Smith przytacza opinię Ernsta Gombricha o magicznej funkcji pierwszych rysunków (np. naskalnych) i w tym znaczeniu ich podobieństwie z budowaniem siedzib chroniących przed siłami natury i jej duchowością ${ }^{2}$. Leszek Maluga, pisząc o specyfice rysunku architektonicznego wobec innych typów obrazów plastycznych, dostrzega, że [...] rysunek architektoniczny jest przypisany do zawodu architekta, ponieważ stanowi materialny ślad procesu projektowania przestrzeni. [...] Oznacza to, że rysunek spetnia role pomocnicza $w$ ogólnym procesie ksztaltowania przestrzeni. Jest jednak podstawowym materialnym dokumentem $w$ fazie powstawania zapisu projektowego, a następnie realizacji zamystu twórczego w rzeczywistej przestrzeni. [...] Przytoczona definicja wymaga jednak rozwinięcia $i$ dokładniejszego omówienia ze względu na różnorodność sytuacji twórczych, w których powstaja zapisy graficzne oraz bogactwo form $i$ środków plastycznych stosowanych przez architektów ${ }^{3}$ [4, s. 17]. Frank Gehry wyraża przekonanie o poszukiwaniu projektowanego budynku przez rysunek, porównując ten wysiłek do aktu rzeźbienia ${ }^{4}$ (za: [2]). Według Romana Ingardena dzieło architektury powstaje dopiero wówczas, gdy dochodzi do materialnej realizacji projektu [5, s. 124]. Jednocześnie z jego opinii Misiągiewicz wnioskuje o [...] zasadności rysunku-projektu jako niezbędnego pośrednika na drodze: idea dzieła i jej realizacja. Projekt dokumentuje rzeczywista twórczość architekta. Wyrażanie myśli poprzez rysunek staje się aktem twórczym. Wszak tylko $w$ ten sposób możliwy jest do osiagnięcia cel projektowania, wspierajacy się na relacji myślenia i postrzegania wzrokowego, zależności, jakiej sens dowodzi Władysław Strzemiński w swojej teorii widzenia $^{5}$ [2, s. 18]. Ważnego podziału na dwa obszary twórczości dokonał Olgierd Czerner, zauważając różnice między rysunkami architektonicznymi (projektowymi do realizacji obiektu oraz wyrażającymi idee) (il. 2) i rysunkami architektury (ukazującymi obiekty istniejące) ${ }^{6}$ (za: [2]) (il. 3).

Podobną opinię Robina Evansa przytacza Leszek Maluga: Rysunek $w$ architekturze nie jest wykonywany w nastepstwie rzeczywistości, lecz poprzedza konstruowanie jej ${ }^{7}$

${ }^{2}$ Historyk sztuki E.H. Gombrich, rozważając źródła sztuki, pisze, że ludzie tworzyli schronienia, by chronić się przed wplywami natury takimi jak deszcz, ale też przed duchami sit przyrody (tłum. M. Suffczyński) [3, s. 6].

3 Autor wyraża przekonanie, że rysunek architektoniczny [...] stanowi materialny ślad procesu projektowania przestrzeni [4, s. 17].

${ }^{4}$ Zaznacza też, że rysunek jest „etapem na drodze do realnego budowania”. Z kolei Raimund Abraham przyznaje rysunkom architektonicznym autonomiczną wartość nawet wtedy, gdy nie prowadzą do realizacji budynku (za: [2, s. 54])

5 Por. [6].

6 Misiągiewicz pisze, że rysunki studialne pozbawione szansy na bezpośrednią materialną realizację obiektu oraz fantazje architektoniczne mogą jednak stanowić „element procedury projektowania”. Przywołuje też dokonany przez Federica Zuccaro podział na rysunki „wewnętrzne” (związane z twórczym myśleniem i poszukiwaniem rozwiązania wyzwania projektowego) oraz ,zewnętrzne” (adresowane na budowę w celu realizacji projektu) [2, s. 262].

7 Autor zauważa, że [...] myśl Evansa odnosi się do zasadniczej funkcji rysunku architektonicznego w procesie projektowania [4, s. 19]. Fantazje i utopie architektoniczne nie mieszczą się wprost w takim
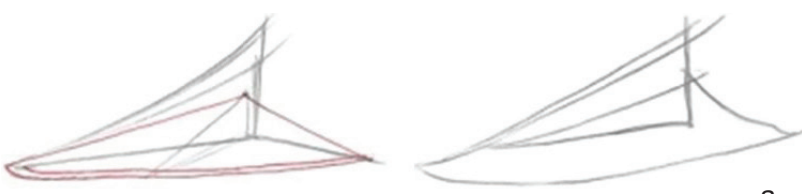

a

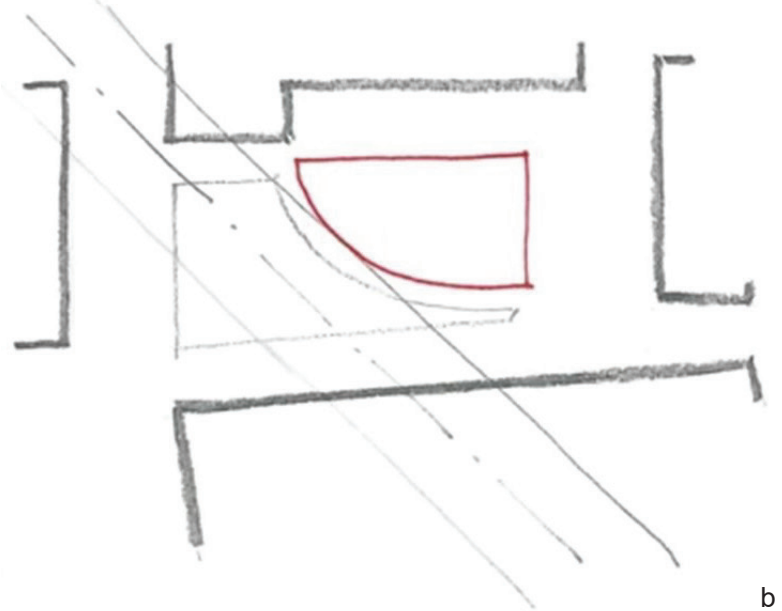

b

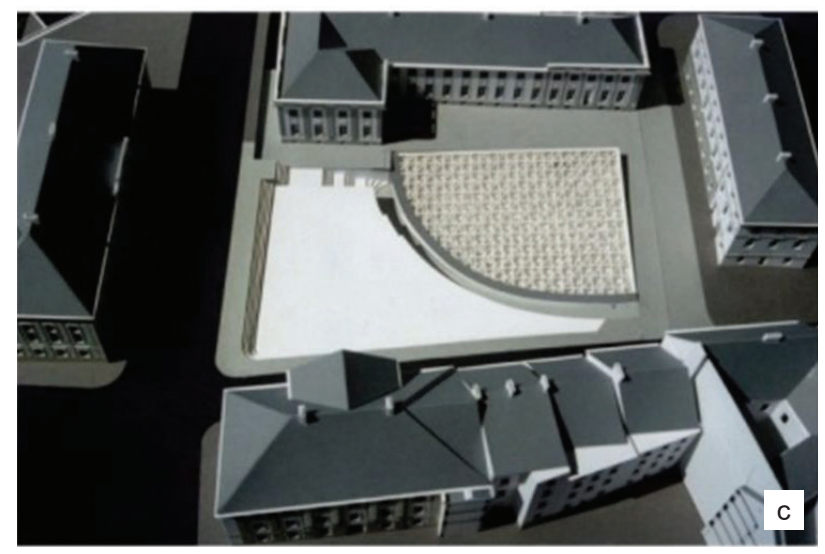

Il. 2. Projekt Galerii Sztuki Współczesnej w Warszawie: a) szkice wstępne, b) ideogram, c) zdjęcie materialnej makiety (autor: M. Suffczyński, projekt dyplomowy, promotor: dr A. Miklaszewski,

Wydział Architektury PW, 1996, ołówek, cienkopis, $20 \times 15 \mathrm{~cm}$ )

Fig. 2. Project of the Contemporary Art Gallery in Warsaw: a) initial sketches, b) ideogram, and c) a photograph of a material model (for the diploma of the M. Suffczyński,

supervisor: PhD Andrzej Miklaszewski, Faculty of Architecture of the WUT, 1996, pencil, fineliner, $20 \times 15 \mathrm{~cm}$ )

realization of objects) (Fig. 2) and drawings which show existing objects ${ }^{6}$ (after: [2]) (Fig. 3).

The design idea is to shape the form of the gallery in such a way, so as to preserve the views of the existing frontages around the parcel in the historical area of the Old Town, and to take into account the spatial and constructional determinants of the W-Z Route's tunnel.

${ }^{6}$ Misiągiewicz writes that studies which will not be later used for the realization of an object as well as architectural fantasies can be "a part of a design procedure". She also makes a reference to the division made by F. Zuccaro into: "internal" drawings (associated with creative thinking and searching for a solution to a design task) and "external" drawings (intended to be used at a construction site) [2, p. 262]. 


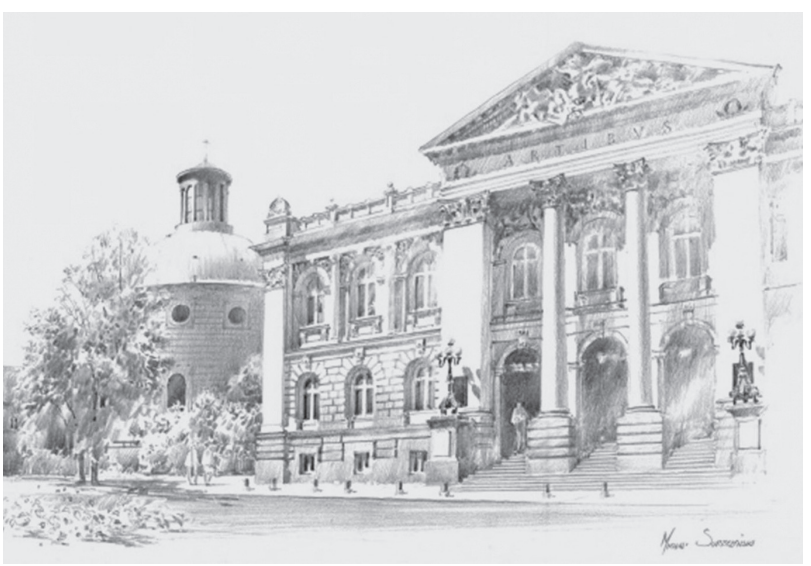

I1. 3. Przykład realistycznego obrazowania z bezpośredniej obserwacji.

Budynki kościoła ewangelicko-augsburskiego pw. św. Trójcy (proj. B. Zug)

i Galerii Zachęta (proj. S. Szyller)

(rys. M. Suffczyński, ołówek, $40 \times 30 \mathrm{~cm}$ )

Fig. 3. An example of realistic observational drawing. The buildings of the The Holy Trinity Evangelical Church of the Augsburg Confession (arch. B. Zug) and the Zacheta National Gallery of Art (arch. S. Szyller) (drawn by M. Suffczyński, pencil, $40 \times 30 \mathrm{~cm}$ )

[4, s. 19]. Mirosław Orzechowski w autorskim definiowaniu rysunku architektonicznego przygląda się [...]jego funkcji skupionej na opisywaniu zjawisk przestrzennych dotyczacych rzeczywistości, tej zastanej, ale $i$ tej planowanej. [...] Znalazłbym miejsce zarówno dla odwzorowań realistycznych, jak $i$ abstrakcji, oraz wszystkiego co jest pomiędzy. Klucz dla klasyfikacji i definicji rysunku architektonicznego stanowitby zawsze cel powstawania rysun$k u[7$, s. 17].

\section{Rysunek strukturalny w komunikacji wizualnej}

W rozmowach ze studentami podczas zajęć w Zakładzie Dziedzictwa Architektonicznego i Sztuki PW zwracamy uwagę na analityczną funkcję zapisów graficznych. Ciekawe w tym aspekcie może okazać się odniesienie do odmiennej estetyki proponowanej w kształceniu architektów w tradycji École des Beaux Arts oraz środowiska Bauhausu, o których będzie mowa w dalszej części artykułu. Obecnie używamy technik zapisu elektronicznego, wzbogacając możliwości przekazu wizualnego pozostającego podstawowym obszarem komunikacji w architekturze.

Rysunek strukturalny trzeba charakteryzować na tle pojęcia rysunku jako wyzwolonej w czasach renesansu dziedziny twórczości. Warto zaznaczyć, że mówimy tu o sztuce europejskiej, bogate dziedzictwo w tym zakresie innych obszarów świata, zwłaszcza Azji, nie jest przedmiotem tego opracowania.

ujęciu, ale mogą pełnić funkcje pomocnicze jako inspiracje w poszukiwaniu nowych form i organizowania przestrzeni.
Saving the visual message aims at highlighting the most important features of the designed form.

A similar opinion by Robin Evans is cited by Leszek Maluga: An architectural drawing does not follow reality but precedes the process of constructing $i t^{7}$ [4, p. 19]. In his own description of architectural drawing Mirosław Orzechowski considers [...] its function focused on depicting spatial reality phenomena, the reality which already exists and the one which is planned at a particular moment. [...] There is a place for realistic representations as well as for abstractions and for everything in between. A key to classifying and making a definition of architectural drawing would always be the aim of drawing [7, p. 17].

\section{Structural drawing in visual communication}

When talking with our students at the Academic Unit of Architectural Heritage and Art at Warsaw University of Technology (WUT), we pay attention to the analytic function of the graphic recording. What is interesting in this aspect and will be discussed below is the reference to a different type of aesthetics, which in the process of educating architects is proposed by the tradition of the École des Beaux-Arts and the tradition of the Bauhaus. Nowadays, we use techniques of electronic recording enriching the possibilities of visual messages, which remains the basic area of communication in architecture.

Structural drawing should not be characterized otherwise than taking into account the concept of drawing as a separate field of art, which was liberated during the Renaissance. At this point, it should be emphasized that here we are dealing with European arts. The abundant heritage of other parts of the world, Asia in particular, is not the subject of this paper.

The most essential form of visual communication in a drawing is the line that represents a symbolic meeting of surfaces with various lighting, textures and colors. In Polish, the very etymology of the word meaning "drawing" (pl: rysunek) is derived from the word meaning "trace" (pl: ślad) or "scratch" (pl: rysa). It can also be observed in other languages, for instance in German - Risse Machen ${ }^{8}$. Ryszard Natusiewicz notices that the power of human imagination and abstract thinking makes it possible to operate with a line which is in fact a border between visually variable areas ${ }^{9}$. This aspect is also pointed out by Ewa M. Górska who emphasizes the brevity and abstractness

7 The author notices that [...] Evan's thought refers to the fundamental function of architectural drawing in a design process. Fantasies and architectural utopia do not fit directly into this approach, but they can perform auxiliary functions as inspirations for finding new forms and organization of space [4, p. 19].

8 In Polish, the etymology of the word rysunek (Eng. "drawing") is associated with the noun rysa (Eng. "crack") and the verb ryć (Eng. "carve"). Professor Dąbrowski refers to the sources of the word rysunek in Latin and other European languages (Greek, Italian, French, English, Russian, German) [8, p. 286].

9 The freehand drawing method is used at most of the faculties of architecture at Polish universities. Drawing is a basic workshop skill in this profession. Professor Natusiewicz's great achievements in the education of students are worth mentioning here [9, p. 9]. 
Najistotniejszą formą przekazu wizualnego rysunku jest obecność linii stanowiącej symboliczne spotkanie płaszczyzn o różnym oświetleniu, fakturach lub kolorze. Już sama etymologia słowa czerpie ze słów oznaczających ślad, rysa, również w językach obcych (np. niemieckie pojęcie risse machen $)^{8}$. Ryszard Natusiewicz zauważa, że siła ludzkiej wyobraźni i myślenia abstrakcyjnego umożliwia operowanie linią będącą $\mathrm{w}$ rzeczywistości granicą między zmiennymi wizualnie obszarami ${ }^{9}$. Na ten aspekt zwraca też uwagę Ewa M. Górska, podkreślając skrótowość i abstrakcyjność przekazu ${ }^{10}$ (il. 4). Jacek Krenz, pisząc o znakach graficznych $\mathrm{w}$ architekturze, wydobywa tę cenną wartość syntezy graficznej we współczesnej komunikacji wizualnej, przyznając ideogramom ważną funkcję ogniskowania idei projektowej ${ }^{11}$ (il. 5). Synteza taka zawsze jest poprzedzona fazami obserwacji i anali$z^{12}$. Sprawność warsztatowa jest ważną umiejętnością, ale tylko w takiej proporcji, w jakiej ma służyć procesowi myślenia. Ciekawą refleksję wyraża Adam Sufliński: [Rysunek] to język informujacy bez ulegania magii stów. Nulla dies sine linea. Te stowa Apellesa od IV wieku p.n.e. przypominaja o konieczności stałego doskonalenia umiejętności płynnego prowadzenia linii, wyrazistości plam, wysublimowanej urody kompozycji, lekkości dotykania papieru $^{13}$ [7, s. 19].

Przy rysowaniu z natury mamy do czynienia z kształtowaniem przedmiotu wzrokowego powstającego $\mathrm{w}$ procesie psychofizycznego wysiłku u rysującego ${ }^{14}$, w projektowaniu

${ }^{8}$ Etymologia słowa rysunek związana jest w języku polskim z rzeczownikiem rysa i czasownikiem ryć. Henryk Dąbrowski odwołuje się do źródeł słowa rysunek w łacinie i innych językach europejskich (greckim, włoskim, francuskim, angielskim, rosyjskim, niemieckim) [8, s. 286].

9 Metoda rysunku odręcznego w kształceniu architektów jest obecna na większości wydziałów architektury polskich uczelni. Operowanie kreską stanowi podstawową umiejętność warsztatową w wykonywaniu zawodu. Należy tu wspomnieć ogromne zasługi prof. Natusiewicza w edukacji studentów i popularyzacji wiedzy o architekturze i metodach obrazowania [9, s. 9].

10 Górska powołuje się na Karela Teissiga piszącego o zdolności do abstrahowania w sztukach plastycznych, czego wizualnym wyrazem jest operowanie kreską (K. Teissig, Techniki rysunku, Warszawa 1983). Zasadniczo różni się to od realistycznego malarstwa opartego na wykorzystaniu barw, których obszary spotykają się w obrazie bezpośrednio, bez uwidocznienia kreski wyznaczającej granice tych obszarów [10, s. 122].

11 W swojej pracy Krenz formułuje to następująco: Na płaszczyźnie projektowej ideogram jest lapidarnym, pojęciowym przewodnikiem $w$ procesie tworzenia przestrzeni architektonicznej. Jest najprościej wyrażonym celem $i$ drogowskazem. Na poziomie odbioru ułatwia odczytanie i interpretację idei zawartej $w$ dziele architektonicznym. Ideogram petni rolę katalizatora umożliwiajacego przekucie idei w tworzywo [11, s. 54].

12 Szczególnie wartościowe jest przekonanie autora o pozostawianiu studentom pewnej swobody w poszukiwaniu środków wyrazu graficznego dla oddania charakterystycznych cech obrazowanego tematu. Takie podejście w procesie edukacji artystycznej umożliwia odkrywanie osobistej wrażliwości i osiąganie ciekawych, często niespodziewanych efektów obrazowania [11, s. 11].

13 Ciekawe są refleksje autora dotyczące postrzegania przestrzeni: Zmysłami wtapiamy się w naturalność przyrody. Widzimy ksztalty, czujemy nastroje wyrażane przez światło: barwę, ciepto, dźwięk, zapach, dotyk, przejrzystość i ruch powietrza [7, s. 19].

14 Wkład prof. Bartla w piśmiennictwo i gromadzenie stanu wiedzy o rysunku perspektywicznym jest ogromny. Świadczy o tym jego

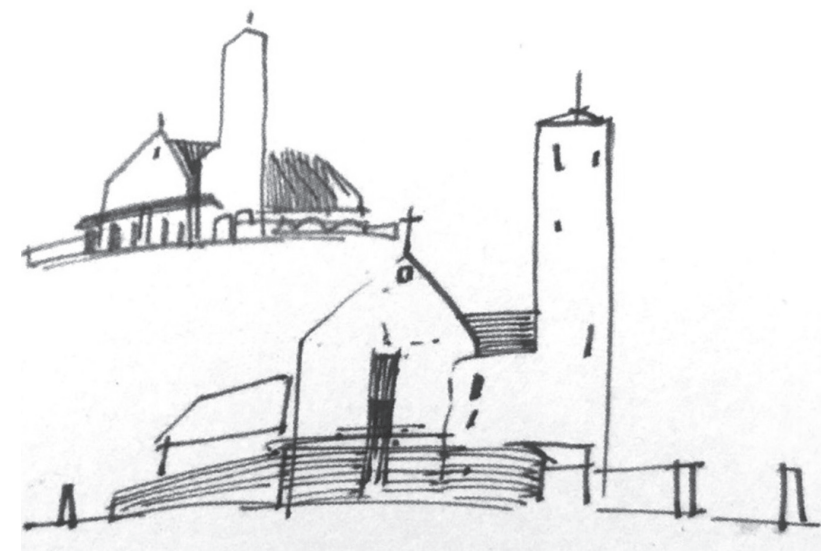

Il. 4. Szkic wstępny widoku do projektu kościoła w Białymstoku (autor: A. Sufliński, tusz i ołówek na papierze, $11 \times 14 \mathrm{~cm}$ )

Fig. 4. An initial sketch for the project of a church in Białystok (author: A. Sufliński, ink and pencil on a paper, $11 \times 14 \mathrm{~cm}$ )

of the message ${ }^{10}$ (Fig. 4). This great value of a graphic synthesis in contemporary visual communication is also highlighted by Jacek Krenz. While writing about graphic signs in architecture, Professor assigns ideograms a great function in revealing a design idea ${ }^{11}$ (Fig. 5). This synthesis is always preceded by the phases of observation and analysis ${ }^{12}$. Workshop refinement is a crucial skill but only in the proportion as it is intended for the thinking process. An interesting thought was expressed by Adam Sufliński: [Drawing] is an informative language which does not succumb to the magic of words.. Nulla dies sine linea. Since the $4^{\text {th }}$ century $B C$ these words of Apelles have been reminding the need for a constant improvement of skills in drawing of lines in a smooth manner, as well as the clarity of spots, sublime beauty of the composition, lightness of touching the paper ${ }^{13}$ [7, p. 19].

When we draw from nature we deal with the shaping of a visual object, which arises in the process of psychophysical effort of a drawing person ${ }^{14}$, while architectural

10 E.M. Górska makes a reference to $\mathrm{K}$. Teissig who wrote about an ability to bring out particular aspects and depicti them, which is visually expressed by drawing (K. Teissig, Techniki rysunku, Warszawa 1983). This is fundamentally different from realistic painting based on the use of colors, the areas of which meet directly in the picture, without the line being visible [10, p. 122].

11 Krenz says: [...] ideogram is a concise, conceptual guide in the process of creating architectural space. It is a goal stated in the simplest way and a signpost. When we consider the reception, ideogram can facilitate recognition and interpretation of the idea contained in architectural work. An ideogram also plays the role of a catalyst which enables an idea to transform into a material [11, p. 54].

12 What is particularly significant is the author's conviction about giving students some freedom in searching for means of graphic expression to express characteristic features of a depicted subject. This approach in the process of artistic education makes it possible to discover personal sensitivity and achieve interesting, often unexpected depiction effects [11, p. 11].

13 What draws attention here are the reflections of the author upon the concept of space: With our senses we blend in with the beauty of nature. We can see shapes, feel atmospheres expressed by light, color, heat, sound, smell, touch, transparency and air movement [7, p. 19].

14 Professor Bartel's contribution to literature and knowledge about perspective drawing is enormous. This is evidenced by his two-volume 

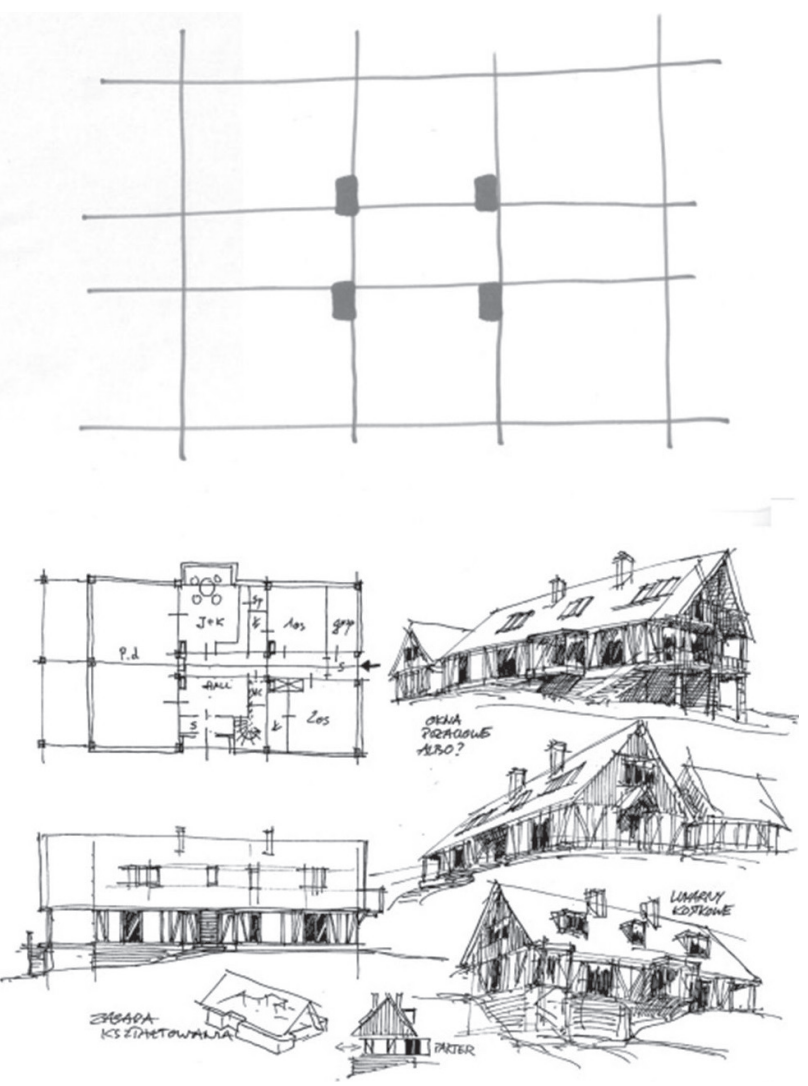

I1. 5. Ideogram i szkice w perspektywie wykonane w procesie projektowania zespołu zabudowy rezydencjonalnej w Pluskach (gm. Stawiguda) dla Rezydencji Warmińskich w latach 2017-2018 (proj. M. Orzechowski, J. Klos, rys. M. Orzechowski)

Fig. 5. An ideogram and perspective sketches made during the process of designing buildings for Warmiński's residence in Pluski (gmina Stawiguda) in the years 2017-2018

(designers: M. Orzechowski, J. Kłos, drawn by M. Orzechowski)

architektonicznym występuje raczej sekwencja interaktywnych reakcji między kształtującymi się na powierzchni obrazu widokami a poszukiwaniem rozwiązań przez projektanta.

Definiowanie rysunku strukturalnego nie jest związane $\mathrm{z}$ nurtem strukturalizmu $\mathrm{w}$ malarstwie, polegającym na głęboko fakturowym, czasami wręcz reliefowym kształtowaniu powierzchni obrazu. Wiąże się z samym pojęciem struktury, której istotą jest przestrzenna relacja poszczególnych jej części, oraz z jej wymiarem wizualnym. Gdy widzimy pod mikroskopem kryształy, zauważamy od razu ich równoległościenny charakter i niekiedy podobieństwo do brył geometrycznych oraz obiektów architektonicznych. Również naturalne formy występujące w przyrodzie stanowić mogą inspirację dla kształtowania struktur budowanych przez człowieka, niekiedy również w skali urbanistycznej.

dwutomowa dysertacja poświęcona perspektywie malarskiej napisana w latach jego twórczej aktywności na Politechnice Lwowskiej poprzedzających wybuch II wojny światowej. Jego autorskie określenie „przedmiotu wzrokowego", świetnie zdefiniowane, stanowi współcześnie jedno z podstawowych pojęć rozważań dotyczących rysunku odręcznego [12, s. 223]. design is featured by a sequence of interactive reactions between views evolving on the surface of an image and the search for solutions by a designer.

The definition of structural drawing is not connected with the trend of structuralism in painting, which focuses on a deeply textured picture surface that sometimes can even resemble a relief. Instead, it is related to the very notion of structure, the essence of which is the spatial relationship of its particular parts and its visual aspect. When we look at crystals through a microscope we can notice their parallelepiped character and sometimes also their resemblance to geometric figures as well as to architectural objects. Some natural forms occurring in nature can likewise inspire to coming up with structures built by humans, sometimes also on an urban scale.

At the Faculty of Architecture WUT, in his PhD thesis, Władysław Fuchs presented his authorial characteristics of structural drawing by depicting its crucial features represented by this academy and reflected in their educational methods as well as in their perception of the concept of space. A similar understanding of the function of drawing appeared already in the Renaissance in Leonardo da Vinci's works, which were analyzed by researchers in the aspect of the "skeletal" way of presenting spatial relationships of solids ${ }^{15}$. An analysis of structures that organize a space of a depicted object and their graphic visibility are the essence of this method (Fig. 6). At this point, it should be noted here that the degree and clarity of this visibility always depend on the purposes for which the image is created. The connection of the graphic intensity of showing the inner edges with the message of a drawing is one of the determinants that distinguish a structural drawing from the broad and traditional concept of drawing as a liberated field of art. It also makes it possible to shape a view in an interesting and visually attractive way, so as to show more than we can see during direct observation. It is also an invaluable skill in creating imaginary, non-existent forms on a flat surface.

Hence, it has a significant role in design. I am convinced that even initial sketches which begin a design process and an architectural illustration as its final step are realizations of structural drawing as long as their author rightly recognizes internal structures of a subject matter (Fig. 7). In this sense the axonometric drawings of the Bauhaus are good examples of structural thinking, even though they do not present internal structures of an object, but rather its idea and objective proportions of bodies without an illusion of perspective or chiaroscuro effects. Axonometry is more related to an unbiased representation of an object than a perspective intended for the observer. The aesthetics of contemporary structural drawings sometimes resemble

dissertation devoted to the painting perspective, written in the years of his creative activity at the Lviv Polytechnic before the outbreak of World War II. His own term "visual object", which was very well defined in the dissertation, nowadays is one of the base concepts raised during discussions on the freehand drawing [12, p. 223].

15 Kemp applies the term "skeletal drawing" to the overall presentation of the structures of a depicted object. In the Warsaw School of Drawing we speak of the notion of "structural drawing", which has a close meaning and was proposed by Fuchs [13, p. 62]. 
Autorską charakterystykę rysunku strukturalnego wyłożył w swojej pracy doktorskiej na Wydziale Architektury PW Władysław Fuchs, opisując jego zasadnicze cechy obecne w metodach kształcenia i myśleniu o przestrzeni w środowisku tej szkoły. Podobne rozumienie funkcji rysunku pojawiło się już w renesansie w pracach Leonarda da Vinci, które badacze analizowali w aspekcie „szkieletowego” sposobu prezentacji zależności przestrzennych bry ${ }^{15}$. Istota tej metody polega więc na analizie struktur organizujących przestrzeń obrazowanego przedmiotu oraz ich graficzne uwidocznienie (il. 6). Trzeba tu zaznaczyć, że stopień i czytelność tego uwidocznienia zależą zawsze od celów, w jakich obraz powstaje. To powiązanie intensywności graficznej ukazywania wewnętrznych krawędzi z zawartością informacyjną rysunku stanowi jeden z wyznaczników odróżniających rysunek strukturalny od szeroko i tradycyjnie rozumianego rysunku jako wyzwolonej dziedziny twórczości artystycznej. Pozwala też na ciekawe i atrakcyjne wizualnie kształtowanie widoku ukazującego więcej, niż możemy zobaczyć w bezpośredniej obserwacji przedmiotu. Jest również bezcenną umiejętnością w kreowaniu na płaskim podłożu obrazu wyobrażonych nieistniejących form.

Z tego wynika jego ważna funkcja w projektowaniu. Wyrażam tu przekonanie, że nawet luźne szkice rozpoczynające proces projektowy oraz finalizująca go ilustracja architektoniczna są przejawami rysowania strukturalnego, o ile towarzyszy im myślowe rozpoznanie przez ich autora struktur wewnętrznych opracowanego tematu (il. 7). W tym sensie aksonometryczne rysunki środowiska Bauhausu stanowią czystą egzemplifikację myślenia strukturalnego, mimo że nie prezentują struktur wewnętrznych obiektu, a raczej jego ideę i obiektywne proporcje brył pozbawione złudzeń perspektywicznych lub efektów światłocieniowych. Aksonometria jest bardziej związana z obiektywnym przedstawianiem obiektu niż dedykowana jego obserwatorowi perspektywa. Estetyka współczesnych rysunków strukturalnych przypomina niekiedy, ze względu na ukazywanie wszystkich krawędzi obrazowanych tematów, prace rosyjskich konstruktywistów, ale różni ją od nich większy stopień finezji w operowaniu kreską i połączenie $\mathrm{z}$ subtelnym światłocieniem.

\section{Warszawska Szkola Architektury wobec tradycji École des Beaux-Arts i Bauhausu}

Źródeł nowożytnej edukacji architektonicznej w Europie upatrywać można w XVII-wiecznych akademiach rysunku stanowiącego kanwę dla malarstwa i rzeźby oraz w konkursach fundowanych przez m.in. papieża Klemensa XI i Antoniego Canovę. Od Ich uczestników oczekiwano rozwiązania $\mathrm{w}$ precyzyjnym rysunku zagadnień

15 Martin Kemp stosuje określenie „rysunku szkieletowego” wobec całościowej prezentacji struktur obrazowanego obiektu, w Warszawskiej Szkole Rysunku mówimy o bliskim w znaczeniu i zaproponowanym przez Fuchsa pojęciu ,rysunku strukturalnego” [13, s. 62]. the works of Russian constructivists due to showing all the edges of the depicted subjects. What makes them distinctive is the enhanced finesse in operating the line and the combination with subtle chiaroscuro.
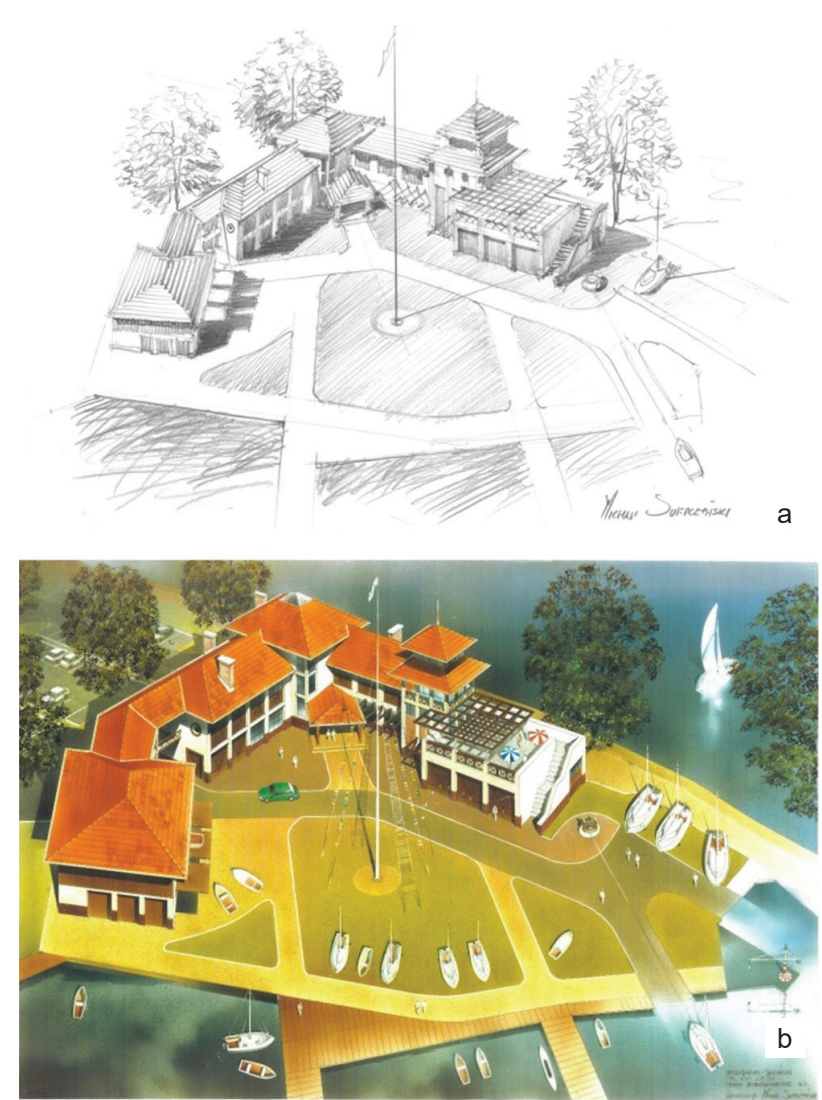

Il. 7. Marina na Cyplu Czerniakowskim w Warszawie: a) monochromatyczny szkic (rys. M. Suffczyński, ołówek, $30 \times 20 \mathrm{~cm}$ ), b) ilustracja (rys. M. Suffczyński, aerograf, akryl, $80 \times 60 \mathrm{~cm}$ ) (proj. A. Orzechowski, K. Jabłoński)

Fig. 7. A marina at Cypel Czerniakowski in Warsaw: a) monochromatic sketch (drawn by M. Suffczyński, pencil, $30 \times 20 \mathrm{~cm}$ ), b) illustration of the concept

(drawn by M. Suffczyński, airbrush, acrylic, $80 \times 60 \mathrm{~cm}$ ) (authors of the project: A. Orzechowski, K. Jabłoński)

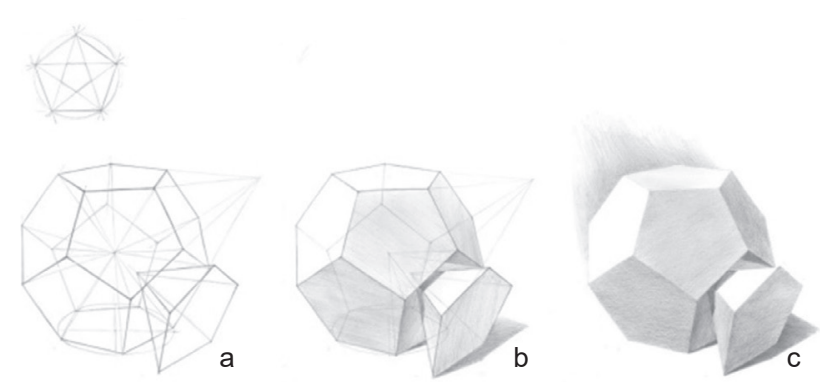

Il. 6. Dwunastościan foremny:

a) rysunek krawędziowy, b) rysunek krawędziowo-światłocieniowy, c) obrazowany powierzchniowo (rys. M. Suffczyński, kredka, $30 \times 40 \mathrm{~cm}$ )

Fig. 6. Symmetrical dodecahedron: a) skeletal drawing, b) skeletal drawing with chiaroscuro, c) surface drawing

(drawn by M. Suffczyński, crayon, $30 \times 40 \mathrm{~cm}$ ) 
projektowych polegających na kształtowaniu elewacji lub obiektu architektonicznego w przestrzeni miejskiej. Założona w Paryżu Académie Royale d'Architecture łączyła w programie kształcenia znajomość geometrii, perspektywy i konstrukcji militarnych z wiedzą o sztuce, a warunkiem rozpoczęcia studiów przez kandydata była umiejętność rysowania. Po ograniczeniu działalności w 1793 r. Akademia została reaktywowana i połączona w $1816 \mathrm{r}$. w Académie des Beaux-Arts razem z Académie de Peinture et de Sculpture i Académie de Musique. Tradycje Académie d'Architecture zostały utrzymane i rozpowszechnione przez dział architektury École des Beaux-Arts. Rysunek był wówczas podstawową umiejętnością warsztatową w zapisie kolejnych etapów procesu projektowania budynku.

Zmiany, jakie przyniosła rewolucja przemysłowa i rozwój w dziedzinie techniki, spowodowały, że architekt został oderwany od problemów technicznych oraz procesów społecznych, a rolę architekta w pewnym sensie przejął konstruktor [14]. Jedną z prób rozwiązania tego problemu było w 1919 r. założenie przez Waltera Gropiusa uczelni artystycznej nowego typu - Bauhausu. Główną ideą szkoły było połączenie umiejętności rzemieślniczych $i$ artystycznych, ale przede wszystkim poszukiwanie nowej estetyki zgodnej z nową zindustrializowaną rzeczywistością.

Neil Bingham określa szkołę Bauhausu jako „eksperymentalną" i przyznaje jej ogromny wpływ na sposoby obrazowania form i kształcenia architektów. Pisze on, że [...] nowe $i$ uproszczone metody przedstawiania budynków [...] ukazują sprzeciw wobec drobiazgowych rysunków neoklasycznych, które powszechnie powstawaty $w$ innych szkołach architektonicznych $[15, \mathrm{~s} .6]^{16}$. Ma on, jak rozumiem, na myśli silny wpływ na te tradycyjne metody kształcenia środowiska paryskiej École des Beaux-Arts. Wspomniane określenie Bauhausu jako szkoły „eksperymentalnej” odnosi się nie tylko do formalnych środków przedstawienia idei, ale przede wszystkim do eksperymentu myślowego. Rysunek jest jedynie narzędziem i pełni funkcję drugorzędną względem idei, jaką prezentuje. Celem w nauczaniu Bauhausu było pobudzenie do myślenia i tworzenia nowych form. Był to sprzeciw wobec kopiowania minionych stylów, a rysunek sam w sobie miał stanowić pożywkę dla wyobraźni. Rysunek, malarstwo i rzeźba wzajemnie na siebie oddziaływały - nie były już tylko formą odwzorowania przyszłego dzieła architektury. Rysunek i malarstwo inspirowały i dawały zaczątek nowej architekturze. Malarstwo i technika wyprzedziły architekturę. To w pracowni malarzy znajdziemy fascynację odkryciami techniki i dziełami konstruktorów. Architekci podążali za tymi zmianami, adaptując nowe wyrazy przekazu wizualnego do prezentacji swoich projektów. Przyczyną tego był

16 Krótkie dzieje funkcjonowania szkoły Bauhausu w latach 1919 1933 spowodowały rozprzestrzenienie w zachodnim świecie uproszczonego wobec akademickiej tradycji ascetycznego przekazu graficznego opartego na widokach aksonometrycznych. Paradoksalnie zamknięcie szkoły przez nazistowski reżim i II wojna światowa spowodowały, że emigracyjne losy wielu autorów i studentów szkoły zaowocowały promocją jej estetyki i metod kształcenia, zwłaszcza w Ameryce Północnej [15].

\section{Warsaw School of Architecture in the face of the tradition of the Beaux-Arts and the Bauhaus}

Sources of the contemporary architectural education in Europe trace back to the academies of drawing from the $17^{\text {th }}$ century as well as in contests organized by, inter alia, Pope Clement XI and Antonio Canova. Participants had to make precise drawings and thereby solve design issues concerning a form of an elevation or an architectural object in urban space. The educational program of the Académie Royale d'Architecture, which was founded in Paris, combined geometry, perspective, and military constructions with the knowledge on art. The crucial factor in the admission process was drawing skill. After limiting its activity in 1793, the Academy was reactivated and merged into the Académie des Beaux-Arts together with the Académie de Peinture et de Sculpture and the Académie de Musique in 1816. The traditions of the Académie d'Architecture were upheld and spread by the architecture department of the École des Beaux-Arts. At that time drawing was a basic workshop skill in recording successive stages of the building design process.

The changes brought about by the industrial revolution and technological development resulted in the separation of architects from technical problems and social processes. The role of architects was to some extent taken over by constructors. One of the attempts to solve this problem was the foundation of a new type of art university - the Bauhaus by Walter Gropius in 1919. The school aimed at combining the craftsmanship and artistic skills, but above all in seeking new esthetics which would be in line with the new industrialized reality.

Neil Bingham describes the Bauhaus school as "experimental" and acknowledges its enormous influence on the ways of representing forms and educating architects. Due to Bingham opinion new and simple graphic means of describing the buildings express objection to neoclassical precise drawings commonly present in other architectural schools ${ }^{16}[15$, p. 6$]$. What he means here is a considerable impact that the Parisian École Beaux-Arts made on these traditional educational methods. The aforementioned definition of the Bauhaus as an "experimental" school refers not only to the formal means of presenting ideas, but above all to a thought experiment. A drawing is only a tool and has a minor function in relation to the idea it presents. What the Bauhaus school strived to attain was to stimulate thinking process and to create new forms. This was intended to raise an objection to copying the old styles. The drawing itself had to nourish imagination. Drawing, painting and sculpture had an influence on each other they were no longer forms of showing a future architectural work. Drawing and painting were inspirations that

16 The short history of the Bauhaus school between 1919 and 1933 in the Western world resulted in the spread of an ascetic graphic message which was based on axonometric views and simplified in relation to an academic tradition. Paradoxically, the closure of the school by the Nazi regime, then World War II and consequently the emigration of many authors and students of the School resulted in the promotion of its esthetics and educational methods, especially in North America [15]. 
gwałtowny rozwój technologiczny. Właśnie dlatego na początku XX w. atelier malarza stało się laboratorium architekta.

Jednym z obowiązkowych podręczników w tej szkole była praca Wassilego Kandinskiego pt. Punkt $i$ linia a płaszczyzna. Przyczynek do analizy elementów malarskich. Autor poszukuje w niej podwalin nowej teorii estetycznej, którą zapoczątkowali impresjoniści, zrywając z podejściem akademickim w malarstwie. W rysunku czy malarstwie akademickim celem było możliwie wierne odwzorowanie tego, co widzimy. Jednak rozwój techniki i nauki w XIX i XX w. sprawił, że ludzie dostrzegli, iż to, co widzimy, to nie musi być prawda ostateczna. Kandinsky rozkłada rysunek na części pierwsze i szuka nowej „gramatyki” kompozycji, przyrównując ją do utworu muzycznego, poszukuje podstawowych napięć między punktem, linią a płaszczyzną [16]. Można w tym podejściu upatrywać związków z idealizmem platońskim. Należy jednak podkreślić, że w szkole Bauhausu równie ważną rolę, o ile nie ważniejszą, pełnił empiryzm. W szkole tej przed wprowadzeniem zajęć teoretycznych kluczowe były warsztaty oraz praktyki na placu budowy. Według Gropiusa, negującego intelektualne szkolenie akademickie, wiedza teoretyczna, deska kreślarska skutkowała [...] zerowym doświadczeniem $w$ pracy $w$ terenie $i$ warsztacie [17, s. 75]. Rzemieślnik miał stać się artystą, a artysta rzemieślnikiem. $Z$ tego też powodu warsztaty prowadziło dwóch dydaktyków - mistrz rzemiosła oraz artysta. Trzeba pamiętać, że inspiracja estetyką kształtowaną na tej uczelni była zaskakująco silna w aspekcie jej relatywnie krótkiego trwania (w latach 1919-1933). W projektach Bauhausu i rosyjskich zwolenników nowej sztuki (grupa artystyczna Unovis, której przedstawicielem był m.in. El Lissitzky) zwraca uwagę skupienie się na wyrazistym graficznie, czasem nawet abstrakcyjnym sposobie prezentacji idei architektonicznej z pominięciem kontekstu otoczenia. Joanna Pętkowska-Hankel zauważa: Program nauczania rysunku $w$ Bauhausie opierat się na przekształcaniu widzianej rzeczywistości, działaniu intuicyjnym, pracy z kolorem, forma i tekstura czy też graficznym eksperymencie $[7, \text { s. 67 }]^{17}$. Lech Kłosiewicz wyrażał przekonanie, że [...] relacja budynek-otoczenie ma znaczenie zasadnicze. To przekonanie było, i zapewne pozostało do dziś, [...] charakterystyczne dla koncepcji kształcenia architektów na Wydziale Architektury Politechniki Warszawskiej [19, s. 268]. Pisząc o metodach kształcenia tej uczelni, wspominał ćwiczenia prowadzone przez Mariana Sulikowskiego w Katedrze Historii Architektury i Sztuki pod opieką naukową Piotra Biegańskiego. Ćwiczenia rozpoczynaly pomiary form istniejacych $w$ naturze: tralki balustrady w Pałacu Wilanowskim, nagrobka na Powązach. Uzasadnieniem tych zadań byt bezpośredni kontakt z miejscem, materiałem, forma [...]. Kolejnym ćwiczeniem było studium form architektury klasycznej, które trzeba było wykreślić,

17 Również Johannes Itten pisze o znaczeniu intuicji w eksperymentowaniu z kolorem i kształtowaniu barwnych kompozycji. Wyraża przekonanie, że prawa barw są dane przez naturę i mogą być odkrywane przez człowieka w procesie uważnej obserwacji [18]. initiated new architecture. The development of painting and technology overtook architecture. A painter's atelier is a place in which we can see the fascination with technological discoveries and constructor's works. Architects followed these changes by adapting new ways of visual expression to present their projects. The reason for this was the rapid technological development. Thus, at the beginning of the $20^{\text {th }}$ century the painter's atelier became the architect's workshop.

One of the obligatory textbooks in this school was Wassily Kandinsky's book Point and Line to Plane. It shows the author's search for foundations for the new esthetic theory initiated by the Impressionists who abandoned the academic approach in painting. The goal of academic drawing and painting was to render visual objects accurately. However, the scientific and technological development in the $19^{\text {th }}$ and $20^{\text {th }}$ centuries made people realize that what they saw did not necessarily had to be the absolute truth. Kandinsky examined the notion of drawing and was looking for a new "grammar" of the composition by comparing it to a musical piece. He was also looking for basic tensions between a point, a line and a surface [16]. This approach can be perceived in relation to Platonic idealism. However, it should be emphasized that it was empiricism that played an equally significant role in the Bauhaus, if not even more significant. In this school, prior to theoretical classes, crucial were the workshops and practices on construction sites. According to Gropius, who denied intellectual academic training, theoretical knowledge and the work done only on a drawing board resulted in "a lack of experience in fieldwork and workshop" [17, p. 75]. The craftsman had to become an artist and the artist a craftsman. For this reason, the workshops were led by two teachers - a master craftsman and an artist. We need to bear in mind that the influence of an esthetic inspiration created in this art school was surprisingly notable when we consider the relatively short period of its existence (from 1919 to 1933). In the projects of the Bauhaus and the Russian followers of new art (an artistic group Unovis, which was represented by, inter alia, El Lissitzky), the focus is on a graphically clear, sometimes even abstract way of presenting an architectural idea without a context of surroundings. Joanna Pętkowska-Hankel said that [...] the curriculum of the Bauhaus was based upon transformation of reality, an intuitive operation, working with colors, forms and textures and graphic experiments $^{17}$ [7, p. 67]. Lech Kłosiewicz was convinced that [...] the relation of a building to its surrounding is essential. This conviction was and presumably remains to this day [...] distinctive for the Faculty of Architecture WUT in terms of the education of architects [19, p. 268]. When writing about the educational methods of this academy he made a reference to practical classes conducted by Marian Sulikowski at the History of Art and Architecture Department, under scientific supervision of Piotr Biegański. The classes started with measurements of forms existing

17 Johannes Itten also writes about the importance of intuition in experimenting with color and shaping of colorful compositions. He believes that the laws of color are given by the nature and can be discovered by man in the process of careful observation [18] 
pokazać ich przestrzenność i strukturę, kompozycję, przestudiować światłocień i proporcje, skalę, a ponad wszystko zrozumieć zawarta w nich logike $[19, \text { s. } 268]^{18}$. Środowisko warszawskiej uczelni traktuje rysunek jako narzędzie badania przestrzeni pozwalające na rozpoznanie jej relacji geometrycznych i nastroju miejsc. Metoda rzutowania środkowego umożliwia ocenę wyglądu projektowanych obiektów w kontekście otoczenia. Tak definiował perspektywę i tak jej funkcję rozumiał Marek Leon Suzin, pisząc o [...] najbardziej zbliżonym do rzeczywistego obrazu doznawanych przez nas wrażeń przestrzennych $^{19}$ [20, s. 59]. Warszawska Szkoła Rysunku uwzględnia taki sposób obrazowania, łącząc go z osobistym postrzeganiem świata przez jej twórców i obecnie kształtujących ją autorów. Stefan Tworkowski i Jerzy Sołtan zalecali swoim uczniom, aby proces poszukiwania rozwiązań zadania projektowego na danym obszarze rozpoznawali rysowaniem opartym na wnikliwej obserwacji ${ }^{20}$. Rozpoznanie istniejącej przestrzeni z jej wartościami kulturowymi powinno zawsze towarzyszyć proponowaniu nowych form, nawet jeżeli będą kształtowane w opozycji do zastanego otoczenia. Podobną opinię o architekturze dopełniającej krajobraz dość poetycko opisuje Peter Zumthor, zauważając głeboki związek form budynków z otoczeniem [21, s. 17]. Również Marian Fikus pisał o poznawaniu miejsca projektowania $\mathrm{z}$ autopsji oraz o znaczeniu rysowania $\mathrm{w}$ poszukiwaniu projektowanej formy ${ }^{21}$. W swojej recenzji mojej rozprawy doktorskiej poświęconej rysunkowi w obrazowaniu architektury zaznaczył, iż Będzie [ona] stużyć architektom, wyrażajacym myśl poprzez rysowanie. Wszyscy studenci pracuja na komputerach, ale proces powstawania i konkretyzowania idei na wszystkich latach musi być podbudowany rysunkiem odręcznym $[23, \text { s. } 1]^{22}$. Szkice są szybkie i bardzo intuicyjne, co pozwala na zaprezentowanie pomysłu w wielu opcjonalnych sekwencjach.

Obecny program nauczania rysunku na warszawskim Wydziale Architektury wyrasta z ponadstuletniego dorobku twórczości nauczycieli akademickich i doświadczeń

18 Kłosiewicz dodaje, iż: Te czasochłonne ćwiczenia później zarzucono, chyba ze szkoda dla rzetelności studiów [19, s. 268]. Ćwiczenia terenowe w swojej istocie łączyły budowanie warsztatu rysunkowego z rozpoznaniem kontekstu przestrzennego i kulturowego.

19 Początki rozumienia i opisania reguł rzutowania środkowego związane są z twórczością mistrzów wczesnego renesansu. Znany drzeworyt Albrechta Dürera ukazujący przenikanie przez tło obrazu wiązki promieni widzenia nie uwzględnia jeszcze binokularnego pola ludzkiego postrzegania, traktując wzrok obserwatora jako jeden geometryczny punkt [20, s. 59].

20 O znaczeniu rozpoznania miejsca projektowania świadczyć może cytowana wypowiedź w trakcie korekt dla studentów prof. Stefana Tworkowskiego: Bardzo proszę opracować sytuację, a potem będziemy mówić o proponowanych rozwiąaniach projektowych (za: [19, s. 268]).

21 Akt rysowania w procesie projektowym prowadzi do obniżenia poziomu abstrakcji, kolejne szkice prowadzą do odpowiedzi na coraz bardziej szczegółowe pytania, ale też wyłaniają nowe zagadnienia do rozwiązania [22, s. 140].

22 Recenzja pracy doktorskiej Rysunek strukturalny $w$ prezentacji przestrzeni architektonicznej obronionej w 2008 r. na Wydziale Architektury Politechniki Warszawskiej pod kierunkiem L. Kłosiewicza [23, s. 1]. in nature: a headstone in Powazki Cemetery, balusters of a railing in Wilanów Palace. By doing such exercises students had a direct contact with a place, a material and a form, [...]. The next practice concerned a study of forms of the classical architecture. Students had to draw them, show their space, structure and composition, study their chiaroscuro, proportions, scale and above all comprehend them $^{18}$ [19, p. 268]. The Warsaw academy treats drawing as a tool for space exploration, which makes it possible to recognize geometric relations in space and the atmosphere of a place. The central projection method allows you to assess the appearance of the designed objects in the context of their surroundings. This is how Marek Leon Suzin defined perspective and understood its function when he wrote about "our spatial impressions which are closest to a real picture"19 [20, p. 59]. The Warsaw School of Drawing takes into account this manner of depicting space by combining it with the personal perception of the world of its artists and current co-authors. Stefan Tworkowski and Jerzy Sołtan recommended to their students that the process of searching for solutions to a design task in a given area should be recognized by drawing based on insightful observation $^{20}$. When new forms are proposed, even if they are later intended to be created in contrast to its existing surroundings, they should not be considered without a recognition of the existing space with all its cultural values. A similar opinion about architecture which complements landscape is described quite poetically by Peter Zumthor noticing deep union of the forms of the buildings with their surrounding space [21, p. 17]. Also, Marian Fikus wrote about getting familiar with a site and about the importance of drawing in searching for a designed form ${ }^{21}$. In his review of my doctoral thesis on drawing in depicting architecture, he noted that [...] it will be useful for architects, who would express their ideas by drawing. All students work on computers, but the process of creating and specifying of ideas always has to be based on freehand drawings ${ }^{22}$ [23, p. 1]. Sketches are done quickly and intuitively, which makes it possible to present an idea in many optional sequences.

18 Professor Kłosiewicz adds: These time-consuming exercises were later abandoned, which was presumably a detriment of the integrity of the studies [19, p. 268]. The field exercises combined building of a drawing workshop with the recognition of a spatial and cultural context.

19 The beginnings of understanding and describing the rules of the central projection are connected with the work of the early Renaissance masters. The well-known woodcut by Albrecht Dürer which shows the transmission of beams of vision through the background of an image does not yet take into account the binocular field of the human perception and perceives the eye of an observer as one geometric point [20, p. 59].

20 The statement by Professor Tworkowski can be a proof for the significance of an insightful observation of an area: I kindly ask you to study the case and then we will talk about the proposed design solutions (after: [19, p. 268]).

21 The act of drawing in a design process leads to a lowering of the level of abstraction, further sketches lead to answers to ever more detailed questions but they also reveal new issues to solve [22, p. 140].

22 A review of doctoral thesis: Rysunek strukturalny $w$ prezentacji przestrzeni architektonicznej at the Faculty of Architecture WUT, prepared under the supervision of L. Kłosiewicz [23, p. 1]. 
edukacji artystycznej. Podstawowe założenia kształtujące dzisiejsze nauczanie sztuk plastycznych w naszej szkole charakteryzował jeden z jej wybitnych twórców i dydaktyków Henryk Dąbrowski. Przykładał on szczególną wagę do rysowania podczas obecności w plenerze pozwalającej na dostrzeganie wzajemnych relacji pejzażu i architektury. W tym procesie dochodzi do sekwencji psychofizycznej aktywności polegającej na wnikliwej obserwacji, zapamiętaniu widzianego obiektu i następnie przenoszeniu widoku na podłoże obrazu przy użyciu narzędzi graficznych i malarskich. Ma to znaczenie nie tylko dla rozbudzania wrażliwości twórczej studentów, ale też buduje ich świadomość kulturową przez obcowanie z ważnymi dla dziedzictwa architektonicznego obiektami w przestrzeniach miejskich i naturalnych. Warto przytoczyć w tym miejscu myśl Gropiusa traktującą o zdobywaniu wiedzy poprzez bezpośrednie doświadczenie. Zwracał on uwagę na znaczenie solidnego wykształcenia modelującego twórcze podejście i wynikającego z łączenia wiedzy akademickiej z własnymi doświadczeniami [17, s. 69].

\section{Podsumowanie}

Obecnie program nauczania rysunku proponowany na pierwszym i drugim roku studiów na warszawskim Wydziale Architektury czerpie w dużej mierze z dorobku École des Beaux-Arts i pewnych elementów Bauhausu, uwzględniając obecne zmiany zachodzące w formach komunikacji wizualnej i bilansie godzin przeznaczonych na ćwiczenia z przedmiotu. Bliskie filozofii Bauhausu jest dopuszczenie większej $\mathrm{w}$ porównaniu $\mathrm{z}$ latami 2. połowy XX w. roli intuicyjnych poszukiwań przez studentów autorskiego kształtowania wizualnych artefaktów. Jednocześnie utrzymanie warsztatu realistycznego obrazowania wywodzącego się z dziedzictwa École des Beaux-Arts jest znakiem rozpoznawczym Warszawskiej Szkoły Rysunku. W ponad stu latach swojego funkcjonowania wykształciła ona wielu twórców architektury, ale też światowej sławy rysowników i projektantów graficznych, jej absolwentami są m.in. Jerzy Stajuda, Rafał Olbiński, Janusz Kapusta. To rzadko spotykane w dzisiejszym świecie, a wciąż obecne w środowisku warszawskiego Wydziału Architektury połączenie kształcenia inżynierskiego i artystycznego stanowi ogromną wartość. Scharakteryzowany powyżej rysunek strukturalny jest cenną metodą analizy i prezentacji form oraz wizualizacji obiektów wyobrażonych. Wartość rysowania z natury i z wyobraźni polega na wykształceniu rozumienia zasad organizujących materialne obiekty i powiązania ich z dziedzictwem kulturowym. Wzrokowy i odczuwalny fizycznie poprzez narzędzie kontakt $\mathrm{z}$ powstającym na powierzchni obrazu wizualnym artefaktem umożliwia interakcję $\mathrm{w}$ procesach projektowania.

Szkoła od czasu jej założenia przez Zygmunta Kamińskiego przeszła długą drogę pokoleniowych przemian i związanych z tym różnic sposobów rysowania kształtujących ją autorów. Zachowała jednak tożsamość wynikającą z kontynuacji i sztafety pokoleń. Istotnym komponentem tej tożsamości jest traktowanie rysunku jako wyrazu
The roots of the current curriculum of teaching drawing at the Warsaw Faculty of Architecture WUT originate from over a hundred years of work by academic teachers and the heritage of artistic education. The basic principles shaping contemporary education of visual arts at our school were represented by one of its outstanding creators and teachers - Henryk Dąbrowski. He attached particular importance to drawing on location, which allows us to see the mutual relations between landscape and architecture. In this process there is a sequence of psychophysical activity, which consists of careful observation, memorization of an object, and then transferring the view to a picture's surface with the use of graphic and painting tools. Its significance lies not only in arousing of students' sensibility as creators but also in building their cultural awareness by dealing with objects that are important for the architectural heritage in urban and natural spaces. Worth quoting here are the words of Gropius about gaining knowledge through direct experience. He emphasized the value of good education shaping creative attitude and resulting from combination of academic knowledge with personal experience [17, p. 69].

\section{Summary}

Currently, the curriculum for drawing offered in the first and second year of studies at the Faculty of Architecture in Warsaw is largely based on the heritage of the École des Beaux-Arts and certain elements of the Bauhaus, taking into account the current changes in the forms of visual communication and the balance of hours devoted to the subject. What is typical for the Bauhaus philosophy is allowing for a greater role of the students' intuitive search for the authorial creation of visual artifacts, compared to the second half of the $20^{\text {th }}$ century. At the same time, the maintenance of the realistic imagery technique derived from the heritage of the École des Beaux-Arts is a distinctive feature of the Warsaw School of Drawing. In over a hundred years of its existence, the school has educated many architects and world-famous illustrators as well as graphic designers. Among its graduates are Jerzy Stajuda, Rafał Olbiński and Janusz Kapusta. This combination of engineering and artistic education, very unique in today's world, and still present in the environment of the Warsaw Faculty of Architecture has a great value. The structural drawing described above is a worthful method of analysis, presentation of forms, and visualization of imagined objects. The value of drawing from nature and imagination lies in the development of understanding of the principles that organize material objects, and their connection to cultural heritage. A visual and a physical contact with an artifact that is created on the image surface enables interaction in design processes.

Since the school was founded by Zygmunt Kamiński, it has naturally experienced many generational changes and therefore also created differences in the methods of drawing among the authors who established the school. However, it has maintained its multi-generational identity. An essential component of this identity is the consideration of a drawing as an expression of beauty and a means of conveying information. In the era of electronic media, 
piękna i nośnika informacji. W epoce mediów elektronicznych odręczne zapisy graficzne zmieniły w dużym stopniu swoją funkcję w wykonywaniu zawodu architekta, ale zachowały ogromne znaczenie w procesach edukacji. handwritten graphic records changed their function in practicing the profession of an architect to a large extent, but they remained highly significant in educational processes.

\section{Bibliografia/References}

[1] Żak D., Teoria malarstwa abstrakcyjnego a Platońska koncepcja sztuki, [w:] A. Kozerska (red.), Podstawy edukacji. Zrównoważony rozwój, t. 9, Wydawnictwo im. Stanisława Podobińskiego Akademii im. Jana Długosza w Częstochowie, Częstochowa 2016, 225-237.

[2] Misiągiewicz M., O prezentacji idei architektonicznej, Politechnika Krakowska, Monografia 291, Kraków 2003.

[3] Schank Smith K., Architects'Drawings. A Selection of Sketches by World Famous Architects Through History, Architectural Press, Elsevier, London 2005.

[4] Maluga L., Autonomiczne rysunki architektoniczne, Oficyna Wydawnicza PWr, Wrocław 2006.

[5] Ingarden R., O dziele architektury, [w:] R. Ingarden, Studia z estetyki, t. 2, PWN, Warszawa 1958, 115-160.

[6] Strzemiński W., Teoria widzenia, Wydawnictwo Literackie, Kraków 1974.

[7] Balcerzak J., Orzechowski M., Pętkowska-Hankel J., Suffczyński M., Sufliński A., Trzupek T., Rysunek architektoniczny $w$ praktyce, czyli jak patrzeć ze zrozumieniem, PWN, Warszawa 2019.

[8] Dąbrowski H., Architektura i krajobraz z lotu ptaka, „Kwartalnik Architektury i Urbanistyki” 2002, t. 47, z. 3, 285-289.

[9] Natusiewicz R., Rysunek architekta, Wydawnictwo PWr, Wrocław 1992

[10] Górska E.M., Studium postaci w technikach monochromatycznych, [w:] B. Siomkajło (red.), Rysunek i malarstwo: problemy podsta- wowe, wybrane zagadnienia, Oficyna Wydawnicza PWr, Wrocław 2001, 119-147.

[11] Krenz J., Architektura znaczeń, Wydawnictwo PG, Gdańsk 1997.

[12] Bartel K., Perspektywa malarska, t. 2, PWN, Warszawa 1958

[13] Kemp M., The Science of Art. Optical themes in western art from Brunelleschi to Seurat, Yale University Press, New Haven-London 1990.

[14] Trzeciak P., Przygody architektury XX wieku, Nasza Księgarnia, Warszawa 1974

[15] Bingham N., 100 lat rysunku architektonicznego 1900-2000, Laurence King Publishing, London 2013.

[16] Kandyński W., Punkt i linia a płaszczyzna. Przyczynek do analizy elementów malarskich, Wydawnictwo Officyna, Łódź 2019.

[17] Gropius W., Petnia architektury, Karakter, Kraków 2014.

[18] Itten J., Sztuka barwy, Wydawnictwo d2d.pl, Kraków 2015.

[19] Kłosiewicz L., Architektura wXX w. - modernizm, postmodernizm, „Kwartalnik Architektury i Urbanistyki” 2002, t. 47, z. 3, 265-284.

[20] Suzin L.M., Perspektywa wykresowa dla architektów, Arkady, Warszawa 1974.

[21] Zumthor P., Myślenie architektura, Karakter, Kraków 2010.

[22] Fikus M., Cechy procesu projektowego w dzialalności twórczej i realizacyjnej, powiazanie praktyki realizacyjnej z teoria i dydaktyka, Wydawnictwo PP, Poznań 1991.

[23] Fikus M., Recenzja pracy doktorskiej pt. Rysunek strukturalny w prezentacji przestrzeni architektonicznej autorstwa Michała Suffczyńskiego, Warszawa 2008 [mpis: WA PW].

\section{Streszczenie}

Przedmiotem artykułu jest funkcja rysunku strukturalnego w twórczości architektonicznej jako metody obrazowania przestrzeni zgodnie z prawami widzenia i perspektywy malarskiej oraz jego rola w kształceniu architektów. Definiowanie rysunku strukturalnego odwołuje się do rozmieszczenia materialnych elementów w przestrzeni oraz ich wizualnego przedstawiania. Celem opracowania jest zapis doświadczeń edukacyjnych Warszawskiej Szkoły Rysunku w środowisku Wydziału Architektury Politechniki Warszawskiej wobec tradycji nauczania École des Beaux-Arts i Bauhausu. Przedstawiono metody graficznej prezentacji form architektonicznych istniejących i projektowanych. Analiza porównawcza sposobów wizualizacji w XX-wiecznym procesie ich kształtowania i przemian uwzględnia zarówno zewnętrzny aspekt obrazowanych obiektów, jak i ich zależności przestrzenne. Wynikające z niej wnioski dotyczą wpływu dziedzictwa edukacji École des Beaux-Arts i Bauhausu na metody ukazywania przestrzeni przez absolwentów Wydziału Architektury Politechniki Warszawskiej oraz różnic charakteryzujących wyżej wymienione uczelnie.

Słowa kluczowe: rysunek strukturalny, Warszawska Szkoła Rysunku, Bauhaus, École des Beaux-Arts

\section{Abstract}

This article discusses the function of structural drawing in architectural works as a method of depicting space according to the laws of vision and perspective, as well as about its role in the education of architects. The definition of structural drawing refers to the arrangement of material elements in space and their visual representation. The paper presents the educational experience of the Warsaw School of Drawing in the environment of the Faculty of Architecture of the Warsaw University of Technology in relation to the teaching tradition at the École des Beaux-Arts and the Bauhaus. It also shows methods of graphic representation of existing as well as designed architectural forms. The comparative analysis of the methods of depiction in the formation and transformation processes from the $20^{\text {th }}$ century takes into account both the external aspect of depicted objects and also their spatial relations. The resulting conclusions concern the impact of the educational heritage of the École des Beaux-Arts and Bauhaus on the methods of presenting space by graduates of the Faculty of Architecture of the Warsaw University of Technology and the differences characterizing the above-mentioned universities.

Key words: structural drawing, Warsaw School of Drawing, Bauhaus, École des Beaux-Arts 